\title{
Kaçınma, Değişim, Gelişim: Yeni Normalde Sürdürülebilir Hareketlilik İçin Bir Anlatı
}

\author{
Hülya Eşki Uğuz ${ }^{1}$ \\ ORCID: 0000-0003-1583-0501
}

\author{
Firat Harun Yilmaz ${ }^{2}$ \\ ORCID: 0000-0003-2838-5400
}

Öz

Kentlerin tarihinde önemli bir yere sahip olan afetler, salgin ve pandemiler kentleri geçmişte olduğu gibi bugün de şekillendirmeye devam etmektedir. 1848'de Londra'daki kolera salginmmn kentsel temizlik konusunda ilk halk sağhı̆̆ı politikasını gündeme getirmesi ve 1871'de Chicago'da çıkan bir yangının ilk gökdelenlere yol açması gibi Covid 19 salgını sonrasında da kentler pandeminin etkilerini en aza indirmek ve kentsel direnci artırmak için yeniden yapılanmaktadır. Bu yeniden yapılanmanın en bariz görünümlerinden birisi de temel erişim ve hareketlilik ihtiyactn çevreye zarar vermeden karşılayan, bağhl olduğu kaynakların yenilenebilir olduğu; yaşam kalitesinin artmasını sağlayan, işlerliği güçlü, toplumsal adaleti destekleme odaklı; eğitim, sağlık gibi temel sosyo-ekonomik araçları en üst düzeyde erişilebilir kılan sürdürülebilir hareketlilik kavramına yapılan vurgu olarak karşımıza çıkmaktadır. Salgın, bir kez daha göstermiştir ki ulaşımı teknik bir sorun olmaktan uzaklaştırtp toplumsal ve mekânsal adalet ekseninde ele alacak ve araç için tasarlanmış mekânı yeniden insanı merkeze alarak kurgulayacak anlatılara geçmiştekinden daha fazla ihtiyacımız vardır. Bu çalışma pandemi sonrası süreçte sürdürülebilirliği sağlarken güvenli ve sağhlılı hareketliliği temin edecek bir anlatı üzerine -Kaçınma, Değiş̧im, Gelişim- olup yeni normalde atılması gereken somut adımları içermektedir.

Anahtar Kelimeler: Pandemi, Kent, Sürdürülebilir Hareketlilik, Anlatı, Kaçınma-Değişim-Gelişim

\footnotetext{
${ }^{1}$ Prof. Dr., Selçuk Üniversitesi, E-posta: hulyaeski@selcuk.edu.tr

${ }^{2}$ Arş. Gör., Selçuk Üniversitesi, E-posta: firatyilmaz@selcuk.edu.tr

idealkent @ Kent Araştırmaları Dergisi (Journal of Urban Studies)

http://idealkentdergisi.com
}

Geliş Tarihi Received Date: 01.10.2021 Kabul Tarihi Accepted Date: 26.12.2021 


\title{
Avoid, Shift, Improve: A Narrative for Sustainable Mobility in the New Normal
}

\author{
Hülya Eşki Uğuz ${ }^{3}$ \\ ORCID: 0000-0003-1583-0501
}

\author{
Firat Harun Yilmaz 4 \\ ORCID: 0000-0003-2838-5400
}

\begin{abstract}
Disasters, epidemics, pandemics have an important place in the history of cities and continue to shape cities today as in the past. After the Covid-19 pandemic, cities are being reconstructed to minimize the effects and increase urban resilience just as the London cholera epidemic in 1848 brought forward the first urban hygiene policy and a fire in Chicago in 1871 led to the first skyscrapers. This reconstruction evidently emerges with the emphasis on the concept of sustainable mobility which meets the basic need for access and mobility without harming the environment, the resources it is renewable; ensures increase of quality of life, is functional, supports social justice; makes the basic socio-economic tools as education, health accessible at the highest level. The pandemic shows that we -more than ever-need narratives to address transportation apart from being a technical issue and address it on the social/spatial justice axis, re-create the space designed for the vehicle by putting people to the center. This study is based on a narrative-avoid, shift, improve- that ensure safe and healthy mobility while ensuring sustainability in the post-pandemic process and includes concrete steps that should be taken in the new normal.
\end{abstract}

Keywords: Pandemic, City, Sustainable Mobility, Narrative, Avoid-shift-improve

${ }^{3}$ Prof. Dr., Selcuk University, E-mail: hulyaeski@selcuk.edu.tr

${ }^{4}$ Res. Asst., Selcuk University, E-mail: firatyilmaz@selcuk.edu.tr

idealkent @ C Kent Araştırmaları Dergisi (Journal of Urban Studies)

http://idealkentdergisi.com

Geliş Tarihi Received Date: 01.10.2021 Kabul Tarihi Accepted Date: 26.12.2021 


\section{Giriş}

Kent ve ulaşım planlaması, 7000 yıllık insan yerleşimleri gelişimi boyunca birikmiş olan insan ölçeğinde kentlerin nasıl oluşturulacağı ile ilgili bilgi ve deneyimi bir kenara bırakarak bilimsel temelden uzaklaşmıştır. Petrolün yakıt olarak ulaşım araçlarında kullanılabilir olduğu andan itibaren planlamanın ölçeği insan olmaktan uzaklaşmış, planlama ölçeği otomobile dönüşmüş, mekânsal yapı otomobile uygun şekilde tasarlanmıştır (Knoflacher ve Öcalır, 2011, s. 56-57). Hareketlilik ile ilgili altyapılar, düzenlemeler, söylemler, uygulamalar ve yaşam tarzları yani "kentsel hareketlilik kültürü" (Heinonen, Czepkiewicz, Árnadóttir ve Ottelin, 2021, s. 3) otomobile uygun şekilde gelişmiştir. Ne var ki, otomobil sürdürülebilir bir ulaşım türü değildir. Otomobil doğa ile çatışmakta ve uyumsuzluk göstermektedir. Araca bağımlı hareketlilik kültürü, trafik tıkanıklığı, kazalar gibi sistemin kendi içindeki sorunların yanı sıra, gürültü, çevre kirliliği, partiküller, komşulukların birbirinden ayrılması gibi ulaşım sisteminin içinde kalmayan etkilere de yol açmaktadır. Tüm bunlar sürdürülemeyen bir sistemin belirleyicileri olmakla birlikte özel aracın çekiciliği ve kullanıcısına sunduğu hareket özgürlüğü sürdürülemeyen yap1ların fark edilmesini engellemektedir (Knoflacher ve Öcalır, 2011, s. 57). Otomobilin, yarattığı toplumsal değişim, dönüştürdüğü kentsel mekân ve sürekli enerji talebi nedeniyle bir tüketim nesnesinden tüketen bir özneye dönüştügünü (Beyazıt, 2021, s. 4) anlayabilmek için küresel ve yıkıcı bir salgın gerekmiştir. Bedenin ve hareketliliğin tutsak kılındığı, evlere, sokaklara, mahallelere hapsolduğumuz ve özgürlüğümüzün kısıtlandığı pandemi bizlere, kentsel hareketlilik kalıplarımızı, sokaklarımızı, mahallemizi ve hayat tarzımızı yeniden düşünmek, meydanlar ve sokaklar gibi kamu alanlarını nasıl kullanmamız gerektiğini sorgulamamız için eşi görülmemiş bir firsat sunmuştur. Motorlu trafiğin egemen olduğu düzenin hareket düzeyimizi düşürdüğünü ve yaşadığımız, çalıştığımız, sosyal etkileşimde bulunduğumuz, eğlendiğimiz, rahatladığımız ve alışveriş yaptığımız sokakları işgal ettiğini görmek farkındalığımızı artırmıştır (Tran, 2020; Yargıç, 2020, s. 10).

Bugün artık ulaşımı teknik bir sorun olmaktan uzaklaştırıp toplumsal ve mekânsal adalet ekseninde ele alacak ve araç için tasarlanmış mekânı yeniden insanı merkeze alarak kurgulayacak anlatılara geçmiştekinden daha fazla ihtiyaç duyduğumuzu biliyoruz. Holden, Banister, Gössling, Gilpin ve Linnerud (2020, s. 4)'un ifade ettiği üzere anlatılar; bir şeyi başarmak ya da bir sorunu çözmek için yapılması gerekenlerin (kısa) iyi yazılmış, güvenilir öyküleridir. Sürdürülebilir hareketlilik adına ihtiyaç duyduğumuz anlatılar, 
sürdürülebilir hareketliliği başarmak için tutarlı bir dizi eylemi, ana stratejileri, temel aktörleri ve rolleri içermelidir. Yine sürdürülebilir hareketlilik ile ilgili anlatıların sürdürülebilir kalkınmanın üç şartıyla yani insan ihtiyaçlarının karşılanması, sosyal adaletin sağlanması ve çevresel sınırlara saygıyla da uyumlu olması gerekir. Bu bağlamda "temel ulaşıma (ihtiyaçlara) erişilebilirlik", "ulaşım hizmetlerine (adil) eşit erişim" ve "ulaşım faaliyetlerinin etkilerinin çevresel sürdürülebilirliği (sınırları) tehdit etmemesi" sürdürülebilir hareketliliğin temel kriterleri olarak ortaya çıkar. Bu çalışmada da araç kullanımına olan ihtiyacı azaltma, ulaşımda özel ulaşımdan toplu ulaşıma geçişi teşvik etme ve düşük karbonlu kişisel ulaşımı bilhassa da elektrikli araçların geniş çapta yaygınlaşmasını destekleme gibi faktörlere vurgu yapan teknolojileri ve sosyal uygulamaları kapsayan ve Kaçınma-Değişim-Gelişim olarak isimlendirilen bir sürdürülebilir hareketlilik anlatısı üzerinde durulacaktır. Anlatılar, yalnızca tanımlayıcı kavramları aktarmaları açısından değil aynı zamanda bizlere sürdürülebilir hareketlilik gibi sosyoteknik geçişlerin nasıl elde edilebileceğini etkileyebilecek vizyonlar sunmaları açısından da anlam taşımaktadır (Griffiths, Rio ve Sovacoll, 2021, s. 3). Pandemi sonrası yeni normal süreçte bir yandan sürdürülebilirliği sağlarken diğer yandan güvenli ve sağlıklı hareketliliği temin edecek politika ve davranışları oluşturup meşrulaştırmak ve siyasi davranış değiş̧iklikleri için gerekli ivmeyi yaratabilmek adına böylesi somut önlemlere/önerilere/anlatılara ihtiyacımız bulunmaktadir (Holden, Linnerud ve Rygg, 2021, s. 2; Lozzi vd., 2020, s. 13).

\section{Kentsel Mekânlar ve Hareketlilik}

Kentsel hareketlilik 19. yüzyıldan itibaren kentsel gelişmeyi ve değişimi şekillendiren temel unsurlardan biri olmuştur. At arabaları, yük taşımakta kullanılan araçlar ile başlayan gelişim ve değişim süreci fosil yakıt temelli araçların hayatımıza girmesi ile hızlanmıştır. İnsanların iş, alışveriş, seyahat, eğitim amacıyla yaptığı yer değiştirmeler geniş kapsamlı bir dönüşüm geçirmiştir. Kentlerde yaşanan nüfus artışı ve kentsel mekânın genişlemesi ile araç kullanımı hayatın olağan bir parçası haline gelmiştir (Wheeler, 2004, s. 71). Hareketliliğin kentsel mekanların yapısında meydana getirdiği değişim Şekil 1'de görülmektedir. 


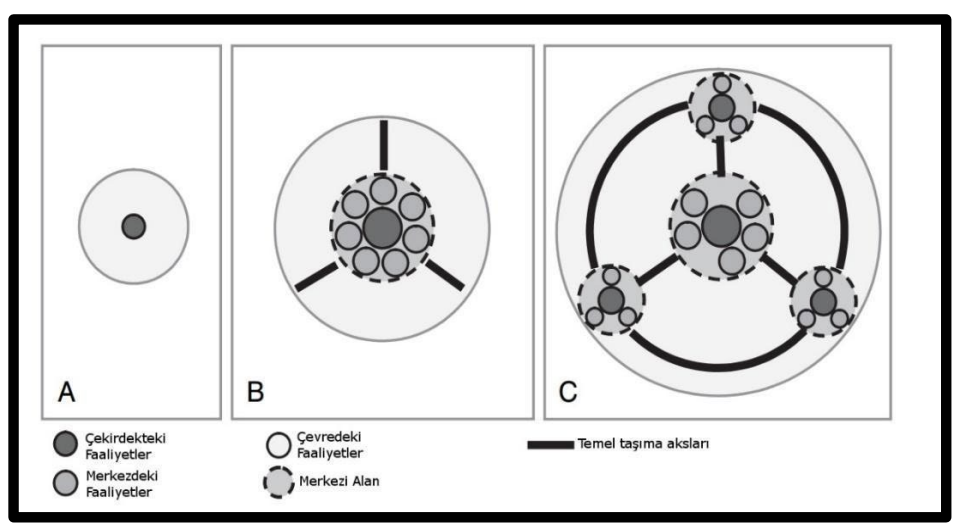

Şekil 1: Kentlerde Hareketlilik ve Mekân İlişkisinin Dönüşümü (Rodrigue, Comtois ve Slack, 2016, s. 174).

İlk aşamada (A) kentler tek merkezlidir ve tek merkez civarında çekirdek/çevre faaliyetleri yürütülmektedir. Bu evrede yürüyüş, at arabası gibi imkânların dışında ulaşım araçlarının var olmaması kentsel yayılmayı engellemiştir. İkinci aşamada (B) kente göç eden bireylerin tek bir merkez etrafında kümelenmesi söz konusudur. Bu aşamada nüfus arttıkça yayılma hızlanmakta ve kentlerin temel taşıma aksları oluşmaktadır. Son aşamada ise (C) kentler çok merkezli bir yapıya bürünmüştür. Günümüzdeki durumu ifade eden bu aşamada kentsel faaliyetler birden fazla merkezde gerçekleşmektedir. Bu durum kentsel merkezlerin birbiri ile bağlantılarının sağlanmasına neden olmaktadır (Rodrigue vd., 2016, s. 175). Hareketlilik günümüzde kentsel ekonomik gelişmenin temel araçlarından biri konumundadır. Doğrudan kentsel hareketliliğe ilişkin yatırımlar insan, mal ve hizmet hareketliliğinde ekonomik maliyetleri azaltmaktadır (Low, 2003, s. 4). Ancak hareketliliğin bir diğer boyutu da kentsel çevrede, toplumda ve kent ekonomisinde meydana gelen olumsuzluklardır. Özellikle gelişmekte olan ülke kentlerinde, bireylerin refah seviyesinin gelişmesi, kentsel yayılma gibi nedenlerden dolayı fosil yakıt temelli araçlar her geçen gün yaygınlaşmaktadır. Bu durum Tablo-1'de yer alan sorunların ortaya çıkışına neden olmaktadır.

Tablo 1. Kentsel Hareketliliğin Neden Olduğu Sorunlar (Gudmundsson, Marsden, Hall ve Josias, 2016, s. 67; Schiller ve Kenworthy, 2017, s. 7)

\begin{tabular}{lll} 
Çevresel Sorunlar & Sosyal Sorunlar & Ekonomik Sorunlar \\
\hline Hava kirliliği & $\begin{array}{l}\text { Kazalar ve Yarattı̆̆ Olum- } \\
\text { suzluklar }\end{array}$ & Ulaşım Altyapı Maliyetleri \\
\hline $\begin{array}{l}\text { Arazi Kullanımı ve Kentsel } \\
\text { Yayılma }\end{array}$ & Yaşam Kalitesinde Düşüş & \\
\hline
\end{tabular}




\begin{tabular}{|c|c|c|}
\hline Küresel İklim Değissikliği & $\begin{array}{l}\text { İnsanlara Yönelik Fiziki ve } \\
\text { Psikolojik Etkiler }\end{array}$ & $\begin{array}{l}\text { Kazaların İnsani ve Ekono- } \\
\text { mik Etkileri }\end{array}$ \\
\hline Ekosistem Tahribatı & $\begin{array}{l}\text { Dezavantajlı Grupların Ula- } \\
\text { şım Hizmetlerine Erişeme- } \\
\text { mesi }\end{array}$ & $\begin{array}{l}\text { Yenilenemez Kaynakların } \\
\text { Tüketilmesi }\end{array}$ \\
\hline $\begin{array}{l}\text { Hidrolojik Etkiler ve Su } \\
\text { Kirliliği }\end{array}$ & $\begin{array}{l}\text { Trafikte Geçirilen Zaman } \\
\text { Kaybı ve Trafiğin Yarattı̆̆ } \\
\text { Huzursuzluklar }\end{array}$ & $\begin{array}{l}\text { Trafik Sıkışılıklarının Eko- } \\
\text { nomik Maliyeti }\end{array}$ \\
\hline Işık ve Gürültü Kirliliği & $\begin{array}{l}\text { Düşük Gelire Sahip Kişilerin } \\
\text { Özel Araç Almaya Zorlan- } \\
\text { ması }\end{array}$ & $\begin{array}{l}\text { Ulaşımla İlişkili Sağlık Mali- } \\
\text { yetleri }\end{array}$ \\
\hline Tehlikeli/zehirli Atıklar & $\begin{array}{l}\text { Kentsel Yayılma Sonucu Or- } \\
\text { taya Çıkan İzole Bölgeler }\end{array}$ & \\
\hline \multirow[t]{2}{*}{ Katı Atıklar } & $\begin{array}{l}\text { Engellilerin ve Araç Sahibi } \\
\text { Olmayanların Ulaşımda } \\
\text { Karşılaştığı Zorluklar }\end{array}$ & \\
\hline & $\begin{array}{l}\text { Kamusal Güvenliğin Azal- } \\
\text { ması }\end{array}$ & \\
\hline
\end{tabular}

Ekonomik açıdan sorunlar altyapı ve kentsel hareketliliğin ekonomik maliyetlerine ilişkindir. Sosyal sorunlar bireylerin ulaşıma erişilebilirliğine, güvenliğe, sosyal birlikteliğe ilişkindir. Çevresel sorunlar ise ulaşımda yenilenemez kaynakların kullanımı sonucunda doğal çevrede meydana gelen tahribata ilişkindir. Tabloda yer alan sorunlar birbiri ile bağlantılıdır. Örneğin kentsel yapı nedeniyle bireylerin özel araç almaya zorlanması ekonomik maliyetleri arttırmaktadır. Özel araç kullanım talebi ile birlikte fiziki altyapı genişlemektedir. Yenilenemez kaynakların kullanımı çevreyi kirletmekte ve oluşan kirlilik kentte yaşayanların sağlığını tehdit etmektedir. Bu süreçte atılması gereken ilk adım kentsel hareketliliğin iyi planlama ve yönetim olmaksızın sorunlara neden olacağını kabul etmektir. Sorunların kabulü ve önlenmesi ise sürdürülebilir kentsel hareketlilik politikaları ile mümkündür. Sürdürülebilir politikalarla temel hareketlilik ihtiyacı karşılanırken ortaya çıkan çevresel, ekonomik ve sosyal sorunların üstesinden de gelinebilmektedir (Schiller, Bruun ve Kenworthy, 2010).

\section{Araç Bağımlı Kentten Sürdürülebilir Hareketliliğe Doğru}

Kentsel hareketlilik ekonomik yapı, kentsel mekânın yapısı, toplumun eğitim ve refah düzeyi, bireylerin yaşam şekilleri gibi farklı değişkenlerce belirlenmektedir. Kentsel hareketlilik için ayrılan arazi varlığı, seyahat maliyeti, seyahat etme niyetinde olan insanların sayısı, araçlara erişilebilirlik ise kentsel 
hareketliliği sınırlandıran değişkenlerdir. Her kent hareketliliğe ilişkin farklılık göstermektedir. Ancak ortak olan nokta ulaşımının meydana getirdiği sorunlardır (Lidskog, Elander ve Brundin, 2003, s. 223). Sorunların ortaya çıması engellenerek kentsel hareketlilik ihtiyacının karşılayacak politikalar her kent yönetiminin temel amaçlarından biridir. Kentsel hareketlilik hizmetlerinin yürütülmesinde iki temel yaklaşım söz konusudur. Bunların ilki neo-liberal yaklaşımdır. Neo-liberal yaklaşım hareketliliği bir piyasa alanı olarak gören ve piyasa ilkeleri doğrultusunda hareket edilmesi gerektiğini söyleyen yaklaşımdır. Bu doğrultuda hizmetler özel sektör eliyle yürütülmektedir. İkinci yaklaşım ise refah modelidir. Bu modelde hizmetlerin yürütülmesinde kamusal aktörler öncü rol oynamaktadır. Bu çerçevede hareketlilik sosyal eşitlik meselesi olarak görülmektedir (Gudmundsson vd., 2016, s. 113). Meakin (2004, s. 10) ise kentsel hareketlilik politikalarının iki şekilde belirlendiğini ifade etmektedir Bunların ilki uygulanacak politikaların önceden belirli olduğu, kentin ihtiyaçlarına cevap veren politika mantığıdır. Bu mantık ile politika uygulayan kentlerde sorunlar, hedefler, öncelikler ve uygulanacak politikalar belirlidir. Aktörlerin sorumlulukları ve düzenlemeler önceden belirlenmiştir. Uygulamada plan ve programlar doğrultusunda hareket edilmektedir. Hareketlilik politikalarına ilişkin diğer yaklaşım ise kısa vadeli, geçici çözüm mantığıdır. Bu mantıkta ilk yaklaşımda belirtilen hususların tam tersi bir durum söz konusudur. Bu mantık çerçevesinde kentlerde politikaların belirlenmesinde aktörlerin sorumlulukları, sorunlar, hedefler, öncelikler ve yapılacak uygulamalar belirsizdir. Ortaya çıkan sorunlar kısa vadeli çözümler ile giderilmeye çalışılmaktadır. Politika yapım ve uygulama süreci karmaşık ve belirsizdir. Bu mantığın hâkim olduğu kentlerde planlı ve sistematik bir şekilde insanlara hareketlilik alternatiflerinin sunulmaması; ulaşım hizmetlerinin geliştirilmemesi nedeniyle sorunlar artmaktadır. Alternatif yokluğu bireyleri motorlu araç kullanımına sevk etmektedir. Kent yönetimleri artan araç sayısına karşın sorunları mevcut altyapının genişletilmesi ile (yeni yollar, geçitler, kavşaklar vb.) çözmeye çalışmaktadır. Altyapı genişlemesi kısa süreli bir rahatlamaya neden olmaktadır ancak bu genişleme ile birlikte, yeni kent merkezlerinin ortaya çıkışı, sorunların uzun vadede devamına neden olmaktadır. Bu doğrultuda bahsedilen ilk yaklaşım çerçevesinde sürdürülebilirlik odaklı politikalara ihtiyaç vardır (Akyol, 2013; Zamora, 2014, s. 141). Şekil 2'de sürdürülebilir kentsel hareketliliği sağlamanın zorlukları yer almaktadir. 


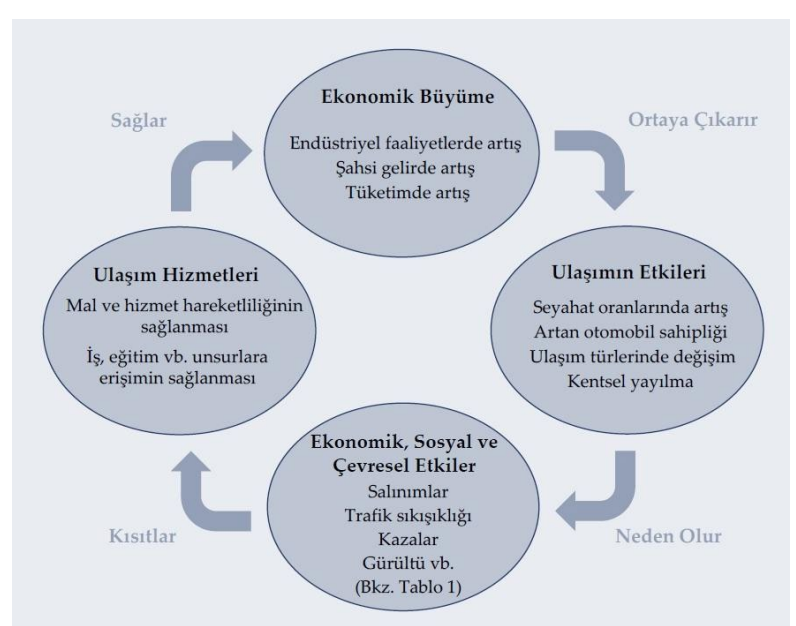

Şekil 2. Hareketliliği Sürdürülebilir Kılmanın Zorlukları (Bräuninger vd., 2012, s. 24).

Ulaşım hizmetleri insan, mal ve hizmet hareketliliğini sağlamaktadır. Ulaşım hizmetleri nihai olarak ekonomik büyümeyi sağlamaktadır. Ekonomik büyüme ise kentsel ulaşımın yapısını etkilemektedir. Şahsi gelirde ve tüketimde yaşanan artış ile birlikte otomobil sahipliği, seyahat oranları artmaktadır. Ulaşım türlerinde yaşanan değişimi ve talebi karşılamak için kentsel altyapı genişlemekte ve bu süreç nihai olarak kentsel yayılma ile sonuçlanmaktadır. Artan araç sayısı, seyahat oranları ve genişleyen altyapı ile birlikte kentsel hareketlilik Tablo 1'de yer alan ekonomik, sosyal ve çevresel sorunlara neden olmaktadır. Bu sürecin son aşamasında ise meydana gelen sorunların ulaşım hizmetlerini kısıtlaması söz konusudur (Bräuninger vd., 2012, s. 2425). Şekil 2'de döngüyü kırmanın aracı ise sürdürülebilir kentsel hareketliliğe ilişkin politikaların belirlenmesidir.

Sürdürülebilir hareketlilik günümüzde çoğu kentte uygulanan geleneksel ulaşım yaklaşımından ayrı bir ideali temsil etmektedir. Bu ideal ulaşım faaliyetinin, enerji yoğunluğunun, yakıt karbon yoğunluğunun azaltılması ve kalıcı yapıyı sürdürülebilir ulaşım araçlarına kaydırarak sera gazı emisyonlarının azaltılması olarak tanımlanabilir (Griffiths vd., 2021, s. 3). Sürdürülebilir hareketliliğin geleneksel yaklaşımdan farkları şu şekilde ifade edilebilir (Banister, 2008, s. 75; Çelik, 2009, s. 706; Schiller ve Kenworthy, 2017, s. 3):

-Geleneksel yaklaşım kentsel hareketlilik ve niceliğe (daha çok ve hızlı ulaşım) vurgu yaparken sürdürülebilir yaklaşım erişilebilirlik ve niteliğe (yakın ve daha iyi ulaşım) vurgu yapmaktadır. 
-Geleneksel yaklaşım tek bir hareketlilik türüne odaklanmaktadır. Farklı türler arasındaki ilişki burada dikkate alınmamaktadır. Sürdürülebilir yaklaşım ise çok boyutludur ve hareketlilik türlerinin birbiri ile olan ilişkilerine bütüncül bir şekilde yaklaşmaktadır.

-Geleneksel yaklaşımda mevcut ulaşım eğilimlerine uyum sağlanması amaçlanmaktadır. Örneğin bireysel araç kullanımı yaygınlaşıyor ise ulaşım altyapısı ve uygulamaları bireysel araçlara göre şekillenmektedir. Sürdürülebilir hareketlilikte ise sosyal, ekonomik ve çevresel açıdan zararlı eğilimler engellenmeye çalışılmaktadır.

-Motorlu araçlar geleneksel yaklaşımın birincil önceliğidir. Sürdürülebilir hareketlilik ise yürüyüş, bisiklet ve toplu taşıma odaklıdır. Geleneksel yaklaşımda trafik ve araç temel odak iken sürdürülebilir hareketlilik insan odakl1dir.

-Geleneksel yaklaşımda planlama ve yönetim süreci kısa vadeli tahminlere göre (tahmin et ve sağla yaklaşımı) yürütülürken sürdürülebilir yaklaşımda uzun vadeli hedef ve planlamalar (ölçme ve buna göre karar verme yaklaşımı) söz konusudur.

-Geleneksel yaklaşımda kentsel altyapı bireylerden gelen taleplere göre sürekli genişletilmektedir. Sürdürülebilir yaklaşımda ise ulaşım talebinin meydana gelecek olumsuzlukları azaltacak şekilde yönetimi söz konusudur.

-Geleneksel yaklaşım ulaşımın sadece ekonomik maliyetlerine odaklanmaktadır. Bu süreçte sosyal ve çevresel maliyetler dikkate alınmamaktadır. Sürdürülebilir yaklaşımda ise sosyal, ekonomik ve çevresel maliyetler birlikte ele alınmaktadır.

Geleneksel yaklaşımın kısa vadeli, trafik ve araç odaklı çözümlerinin kentlerde meydana gelen sorunları çözüme kavuşturmayacağı açıktır. Sorunların çözümü temel erişim ve hareketlilik ihtiyacını çevreye zarar vermeden karşılayan, bağlı olduğu kaynakların yenilenebilir olduğu; yaşam kalitesinin artmasını sağlayan, işlerliği güçlü, toplumsal adaleti destekleme odakll; güvenlik, eğitim, sağlık gibi temel sosyo-ekonomik araçları en üst düzeyde erişilebilir kılan sürdürülebilir hareketlilik ile mümkündür (Schiller ve Kenworthy, 1999, s. 30).

Kentsel alanda sürdürülebilir hareketlilik çerçevesinde yapılacak uygulamaların hayata geçirilebilmesi ekonomik, sosyal ve çevresel hedeflerin ortaya konulmasını gerektirmektedir. 
Tablo 2. Sürdürülebilir Hareketliliğin Amaçları ve Alt Hedefleri (Erdoğan, 2014, s. 4; Gudmundsson, 2004, s. 45; Litman, 2016, s. 5)

\begin{tabular}{|c|c|}
\hline Amaç & Alt Hedefler \\
\hline \multicolumn{2}{|l|}{ Ekonomik } \\
\hline \multirow[t]{4}{*}{ Ekonomik Üretkenlik } & Ulaşım sisteminin verimliliği \\
\hline & Ulaşım sistemi entegrasyonu \\
\hline & Erişilebilirliği arttırmak \\
\hline & Verimli fiyatlama ve teşvikler \\
\hline Ekonomik Gelişme & Daha çok istihdam ve güçlü yerel ekonomi \\
\hline Enerji Verimliliği & $\begin{array}{l}\text { Petrol ithalatı başta olmak üzere enerji mali- } \\
\text { yetlerini düşürmek }\end{array}$ \\
\hline Yeterlilik & $\begin{array}{l}\text { Temel ulaşım hizmetlerine erişimin uygun fi- } \\
\text { yatla sağlanması }\end{array}$ \\
\hline Verimlilik & $\begin{array}{l}\text { Maliyet verimli ulaşım uygulamaları, yeni- } \\
\text { likçi ulaşım araçları }\end{array}$ \\
\hline \multicolumn{2}{|r|}{ 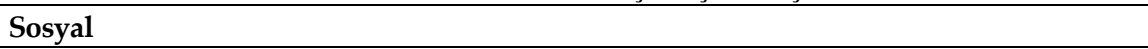 } \\
\hline Eşitlik/ Adalet & $\begin{array}{l}\text { Engelli, düşük gelir sahipleri vb. grupların } \\
\text { ulaşım hizmetlerinden yararlanabilmesi }\end{array}$ \\
\hline Güvenlik/Sağlık & $\begin{array}{l}\text { Kaza oranlarının azaltılması ve bireysel hare- } \\
\text { ketliliğin artırılması }\end{array}$ \\
\hline Kültürel Mirasın Korunması & $\begin{array}{l}\text { Kültürel mirasa saygı ve kültürel aktivitele- } \\
\text { rin desteklenmesi }\end{array}$ \\
\hline \multicolumn{2}{|l|}{ Çevresel } \\
\hline İklim Değişikliğini Önleme & $\begin{array}{l}\text { Salınımların azaltılması, iklim değişikliğinin } \\
\text { etkilerinin hafifletilmesi }\end{array}$ \\
\hline Hava Kirliliğini Önleme & $\begin{array}{l}\text { Hava kirliliği azaltma, yüksek hava kalitesi } \\
\text { sağlama }\end{array}$ \\
\hline Gürülttü Kirliliği Önleme & Gürültü kirliliği oranını azaltma \\
\hline $\begin{array}{l}\text { Su kalitesini koruma ve hidrolojik dön- } \\
\text { güye ilişkin zararları azaltma }\end{array}$ & $\begin{array}{l}\text { Ulaşım kaynaklı su kirliliğinin azaltılması, } \\
\text { geçirimsiz yüzey oranlarını azaltma }\end{array}$ \\
\hline $\begin{array}{l}\text { Açık alanların ve biyolojik çeşitliliğin ko- } \\
\text { runması }\end{array}$ & $\begin{array}{l}\text { Ulaşım kaynaklı arazi kullanımını azalma, } \\
\text { doğal yaşam alanlarını koruma }\end{array}$ \\
\hline \multicolumn{2}{|l|}{ Politika ve Planlama } \\
\hline $\begin{array}{l}\text { Bütünleşmiş, kapsamlı ve kapsayıcı plan- } \\
\text { lama }\end{array}$ & $\begin{array}{l}\text { Açık biçimde tanımlanmış planlama süreci, } \\
\text { entegre ve kapsamlı analiz, vatandaş katı- } \\
\text { lımı, en az maliyetle planlama ve fonlama }\end{array}$ \\
\hline
\end{tabular}

Sürdürülebilir hareketlilik ekonomik açıdan verimli olmak durumundadır. Bunu sağlamanın araçları verimli vergilendirme uygulamaları, yenilenemez enerjiye bağımlılı̆̆ azaltarak enerji ithalatını sınırlamak, ulaşımı toplumun bütün kesimlerinin karşılayabileceği şekilde fiyatlandırmaktır. Farklı ulaşım biçimleri arasında entegrasyonu sağlamak, ekonomik açıdan düşük maliyetli ulaşım modellerini kentlerde uygulamak ekonomik verimliliği sağlamaktadır. (Kennedy, Miller, Shalaby, Maclean ve Coleman, 2005, s. 395; 
OECD, 1996, s. 64). Sosyal açıdan dezavantajlı grupları dışlamaksızın herkese hizmetlere eşit erişim imkânı sunan, toplumsal fırsat eşitliğini temel alan, altyapı planlamasında kültürel ögeleri koruyan, kazaları önleyici tedbirler alarak trafik güvenliğini sağlayan yaklaşımlar sürdürülebilir niteliktedir (Cirit, 2014, s. 17). Çevresel açıdan hareketlilik ihtiyacını karşılarken yenilenebilir kaynakları yenilenme oranlarının altında; yenilenemez kaynakları ise ikame edilebilme oranlarının altında kullanan modeller sürdürülebilirdir (OECD, 1996, s. 12). Sera gazı salınımı düşük çevre dostu ulaşım araçlarının kullanıldığı bu modelde hava, su ve gürültü kirliliğini azaltmak; arazi kullanımını azaltarak kentin doğasına yönelik tahribatı engellemek temel hedeftir.

Sürdürülebilir hareketliliğin uygulanmasının nihai araçları etkin planlama ve yönetimdir. Bu süreçte kentsel altyapı analiz edilerek (fırsatlar, zorluklar ve hedefler) eylem planı hazırlanması söz konusudur. Eylem planının başarılı bir biçimde uygulanması ise aktif yurttaş katılımı ile mümkündür.

\section{Anlatı: Sürdürülebilir Hareketlilikte Kaçınma-Değişim-Gelişim}

Kaçınma-Değişim-Gelişim (Avoid-Shift-Improve) sürdürülebilir kentsel hareketlilik politikalarının belirlenmesinde kullanılan yaklaşımlardan bir tanesidir5. Dalkmann ve Branningan (2007) tarafından Alman Uluslararası İşbirliği Kurumu (GIZ) Sürdürülebilir Kentsel Ulaşım Projesi (SUTP) kapsamında başlangıçta ulaşımın küresel iklim değişikliği üzerindeki etkilerini hafifletmeye dönük bir politika önerisi olarak ortaya çıkan yaklaşımın zaman içerisinde kapsamı genişlemiştir (Bakker, Zuidgeest, De Coninck ve Huizenga, 2014, s. 335). Jafri (2014) K-D-G'nin geleneksel yaklaşımın arz talep mantığ1nın neden olduğu eksikliklere bir cevap olarak geliştirildiğini ve sürdürülebilir kentsel hareketlilik politikalarını oluşturmada bir çıkış noktası olabileceğini ifade etmektedir.

\footnotetext{
${ }^{5}$ Sürdürülebilir kentsel ulaşım politikalarının belirlenmesinde kullanılan diğer yaklaşımlarsa; Kaçınma-Değişim-Gelişim-Finanslama, Sürdürülebilir Kentsel Hareketlilik Önlemleri (Macário ve Marques, 2008), Gösterge Temelli Sürdürülebilir Ulaşım Politikaları (Haghshenas ve Vaziri, 2012), Yeni Hareketlilik, Kentsel Lojistik, Akıllı Sistem İşletimi, Yaşanabilirlik Temelli Politikalar (Cheba ve Saniuk, 2016; Goldman ve Gorham, 2006), Alternatif Ulaşım Modlarına Geçiş, Arazi Kullanımı ve Ulaşım Planlama Entegrasyonu, Alternatif Yakıt ve Araç Politikaları (Aftabuzzaman ve Mazloumi, 2011) şeklinde sıralanabilir.
} 


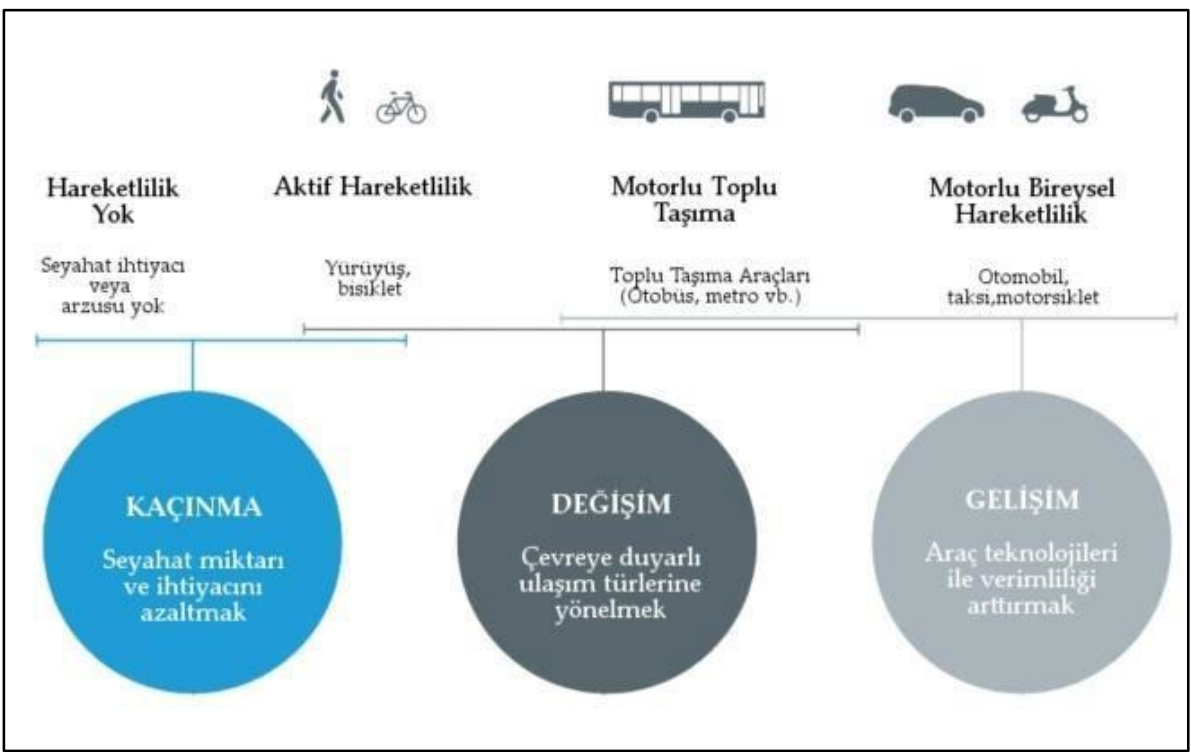

Şekil 2. Sürdürülebilir Ulaşımda Kaçınma Değişim Gelişim Yaklaşımı (Global Transport Knowledge Partnership, 2020)

Anlatının ilk boyutunu oluşturan "Kaçınma/Azaltma" aşaması seyahat ihtiyacını azaltmak veya seyahatten kaçınmak için yapılması gerekenleri ifade etmektedir. Değişim boyutu ulaşımda çevreye duyarlı ulaşım türlerine geçiş sürecini içermekteyken, gelişim boyutu ise kaynak verimliliğinin sağlanması için yapılması gerekenleri ifade etmektedir (Dalkmann ve Brannigan, 2007, s. 7). K-D-G içerisindeki boyutlar sürdürülebilir hareketliliğin aşamaları olarak değerlendirilebilir. Bu çerçevede öncelikle seyahat ihtiyacından kaçınılmalı bu mümkün değilse seyahat miktarı azaltılmalıdır. Seyahat edilmek isteniyorsa çevreye duyarlı ulaşım türleri tercih edilmelidir. Son aşamada ise eğer araç kullanımı söz konusu ise kaynak ve enerji verimliliği sağlanmalıdır.

Kaçınma/azaltmayı sağlamanın ilk yolu kentsel planlamadır. Arazi kullanımı ve ulaşımın birlikte değerlendirildiği yaklaşımlardan biri Toplu Taşıma Odaklı Kentsel Gelişmedir (Transit Oriented Development). Bu yaklaşım karma kullanım aracılığı ile toplu taşımaya erişimin en üst seviyede olduğu iş ve yaşam alanlarının planlamasını ifade etmektedir. Planlamada iş ve yaşam alanları arasında toplu taşıma araçlarına erişim uzaklığı 400 ila 800 metredir. Bu modelde ulaşım istasyonları çevresinde yüksek yoğunluklu yerleşimler bulunmaktadır. Bu yaklaşımın uygulanması bireysel araç kullanımından kaçınılmasını teşvik etmektedir. Ayrıca ulaşımda geçirilen süre ve mesafe azalmaktadır (Jaiswal, Rathore ve Jain, 2012, s. 60; Zamora, 2014, s. 147). 
Kaçınma/azaltmayı sağlamanın ikinci yolu ise iletişim teknolojileri aracılığ ile kentsel hareketliliği ikame edebilecek çözümlerin geliştirilmesidir (Bos ve Temme, 2014, s. 4). Koronavirüs pandemisi boyunca hareketlilikten kaçınma bir zorunluluk haline gelmiştir. Zorunlu olan ve olmayan hareketliliğin arasında ayrım yapılarak sinırlandırmaların yapılması, seyahat kısıtlamaları, kapanma süreçleri, alışveriş gibi aktivitelerin kısıtlanması hareketlilikten kaçınmayı zorunlu kılmıştır. Uzaktan eğitim, uzaktan çalışma, esnek çalışma düzeni, sanal konferans ve toplantıların yaygınlaşması hareketlilik ihtiyacının azalması veya kaçınma ile sonuçlanmaktadır. Bu uygulamaların uygun olduğu takdirde pandemi sonrası süreçte de hayata geçirilmesi kaçınmayı sağlayacaktır. Yine e-devlet uygulamalarının yaygınlaştırılması, geliştirilmesi ve erişilebilirliğin sağlanması hareketlilik ihtiyacını azaltma yollarından biridir (Global Transport Knowledge Partnership, 2020).

Kaçınma/azaltmaya yönelik üçüncü yol ise motorlu araç kullanımını fiyatlandırmaktır. Havuç ve sopa yaklaşımı olarak nitelendirilen politikalarda fiyatlandırma kapsamına bireysel araç sahipleri girerken, toplu taşıma, bisiklet ve yürüyüş teşvik edilmektedir (Asian Development Bank, 2009, s. 39). Bireysel araç kullanımı belirli nokta ve saatlerde fiyatlandırıldığı takdirde hareketliliği azaltmak mümkündür. Kent içi park yerlerinin kontrolü, trafik sıkışıklı̆̆ fiyatlandırması, zirve saatlerde daha fazla park ücretlendirmesi, kent merkezine girişin fiyatlandırılması bu doğrultuda kullanılabilecek uygulamalardır. Yine kent merkezlerinde araç girişine kapalı alanların oluşturulması, park sürelerinin sınırlandırılması bireysel araç kullanımını azaltmaktadir.

Kent yönetimleri ulaşımda geçirilen zamanın azaltılması için trafik durumuna ilişkin eş zamanlı bilgilendirmeyi sağlayacak araçları sunmalıdır. Trafiğin durumuna ilişkin bilgilendirmeyi sağlayacak mobil uygulamalar, internet siteleri bu araçlara örnektir. Bilgi edinmeyi sağlayan araçların yanı sıra akıllı trafik uygulamaları ile kentsel hareketliliğin düzenlenmesi hareketlilik boyunca geçen süreyi azaltmanın bir diğer yoludur. Bu çerçevede akıllı uygulamaları kaçınma/azaltmaya dönük dördüncü yol olarak nitelendirmek mümkündür (Akyol, 2013, s. 299; Lewis, 2015, s. 22; Zamora, 2014, s. 144). Araç paylaşımını teşvik etme politikaları ve uygulamalar kaçınma/azaltmanın beşinci yolunu oluşturmaktadır. Araç paylaşım örgütlenmesi özel sektör, kent yönetimleri veya bireylerin kendi aralarında oluşturdukları bir birliği ifade etmektedir. Örgütlenmeler genellikle kent merkezlerinde veya ana ulaşım hatlarının bulunduğu bölgelerde kurulmaktadır. Araç istasyonu olan 
bölgelerde bireyler aldıkları aracı iş, eğitim gibi faaliyetler amacıyla kullanabilmektedir. Kentlerin belirli noktalarında veya birbirine yakın oturan bireylerin oluşturdukları paylaşım örgütlenmeleri aracılığıyla ulaşım ihtiyacı daha az araç kullanımı ile sağlanmaktadır (Katzev, 2003, s. 67). Kaçınma/ azaltmaya yönelik son yol halkın kentsel ulaşıma ilişkin farkındalık düzeyinin arttırılmasıdır. Eğitim çalıştayları, bilgilendirme faaliyetleri, araçsız gün (carfree days) faaliyeti farkındalık düzeyini artırmaya dönük uygulama örnekleridir.

K-D-G anlatısında "değişim boyutu" çevreye duyarlı hareketlilik türlerine yönelmeyi ifade etmektedir. Değişimin ilk yolu aktif hareketlilik türlerinin kullanılmasına yönelik politikalardır. Havayı kirletmemesi, daha az alan kullanılması, kaza oranının motorlu taşıtlara oranla düşük düzeyde olması, trafik sıkışıklığını ortadan kaldırması, insan sağlığı açısından faydalı olması aktif hareketlilik türlerini tercih edilebilir kılmaktadır (Gwilliam, 2002, s. 125).

Pandemi sürecinde aktif hareketlilik türleri bireysel araç kullanımı ve toplu taşımaya alternatif olarak ön plana çıkmıştır. Bert vd. (2020, s. 3) ABD, Avrupa ve Çin'de pandemi sürecinde kentsel hareketliliğe ilişkin yaptıkları araştırmada bütün bölgelerde aktif hareketliliğin \%21 ila \%59 arasında artış gösterdiğini tespit etmişlerdir. Bisiklet satışları da bu süreçte artış göstermiştir. Örneğin İngiltere' de satışlar \%677 oranında artmış; ABD' de bisiklete olan talep fazlalığ 2020 yılı nisan ayında arzın yetersiz olmasına neden olmuştur. Pandemi sürecinde ulusal düzeyde aktif hareketliliği destekleme amacıyla da programlar başlatılmıştır. Örneğin İtalya'da bisiklet satın alımı için, Fransa'da ise bisiklet tamiri için parasal destek programı başlatılmıştır. Kentsel düzeyde ise aktif hareketliliği teşvik amacıyla pandemi sürecinde Berlin, Leeds, Paris, Brüksel kentlerinde araç kullanımına kapalı yerlerin sayısı arttırılmış ve bisiklet kullanımını teşvik amacıyla geçici bisiklet yolları (pop-up bike lines) oluşturulmuştur (Lozzi vd., 2020, s. 9). Milan kentinde ise pandemi sonrası sürdürülebilir hareketliliği amaçlayan bir adaptasyon stratejisi (Open Streets) yürürlüğe konulmuştur. Strateji kaçınma-değişim-gelişim anlatısına benzer nitelikte seyahat ihtiyacını azaltmayı, hareketlilik alternatiflerini arttırmayı, sağlık önlemlerini almayı ve aktif hareketliliği teşvik etmeyi amaçlamaktadır (Comune di Milano, 2020; OECD, 2020, s. 30). Bu çerçevede pandeminin aktif hareketliliği yeniden düşünme için bir fırsat yarattığını ifade etmek mümkündür (Budd ve Ison, 2020, s. 3; Comune di Milano, 2020, s. 5; Deponte, Fossa ve Gorrini, 2020, s. 142). 
Değişim boyutu çerçevesinde aktif hareketliliğe ilişkin ele alınması gereken ilk husus yürüyüştür. Jeff Speck'in kentsel alanlarda yürünebilirliğe ilişkin önerdiği Genel Yürünebilirlik Teorisine göre kentsel çevrede yürünebilirliği belirleyen temel unsurlar şunlardır: 1) Yürüme mesafesinde kentsel hizmetlerin varlığı, 2) Yürüyüşs sırasında bireylerin tecrübe ettiği güvenlik ve rahatlık düzeyi 3) Kentsel alanların mimari yapı ve sosyal bağlam açısından çekiciliği (Gorrini ve Bertini, 2018, s. 356; Speck, 2013). Birinci unsur açısından kentlerin kompakt bir şekilde tasarlanması yürümeyi teşvik edici bir unsurdur. Yine kentlerde tek işlevli bölgeler yerine birden fazla işlevi (seyahat, barınma, iş) yerine getiren bölgelerin varlığı yürüyüşü teşvik etmektedir (Dovey ve Pafka, 2020, s. 96-99). Ancak altyapı planlamasında motorlu araçlara öncelik verilmesi yürüyüş imkânlarının kısıtlanması ile sonuçlanmaktadır. Yol, kaldırım ve geçitlerin planlamasında yaya ve bisiklet odaklı bir altyapının oluşturulması kısa mesafelerde bireyleri yürümeye teşvik etmektedir. Güvenlik ve rahatık düzeyi açısından kent içi ışıklandırma, güvenlik ve yürünebilir yolların varlığı gereklidir. Yürüyüşün tercih edilebilir olması yayalara yardımcı araçların (yol gösterici levhalar, bilgilendirme levhaları, umumi tuvaletler, kent mobilyaları) varlığ1 ile mümkündür. Bu süreçte yürüyüşü mümkün kılan ve teşvik eden bir altyapının yanı sıra mevcut engeller ortadan kaldırılmalıdır. Altyapı oluşturma sürecine ek olarak politikaların belirlenmesinde yürüyüş ve bisiklet kullanımına yönelik trafik yönetimlerine yaya veya bisiklet uzmanları atanmalıdır (Asian Development Bank, 2009, s. 43; Zamora, 2014, s. 146).

Aktif hareketliliğe ilişkin politikalarda ikinci husus bisiklet kullanımıdır. Kentlerin coğrafi yapıları ve büyüklügü bisiklet kullanımını belirleyen temel faktörlerdir. Bisiklet yollarında bekleme süreleri, yollardaki engeller, hız ve alan yasakları, seyahat süreleri, motorlu araçlardan yavaş olması bisikletin dezavantajları olarak görülmektedir. Fiziki çaba gerektirmesi ve hava koşullarına bağlı olarak kullanım imkânlarının değişmesi bisiklet tercihini etkilemektedir (Heinen vd., 2010, s. 59; Rietveld ve Daniel, 2004, s. 531-533). Toplumda yerleşik bir bisiklet kültürünün bulunmaması, bisikletin bir araç olarak kabul edilmemesi ve altyapıda bisiklete yer verilmemesi bisikletin tercih edilmesinin önündeki diğer engellerdir (Mert ve Öcalır, 2010, s. 228). Ancak motorlu araçlar ile karşılaştırıldığında bisikletin ekonomik, sosyal ve çevresel yönden sürdürülebilir bir araç olduğu kaçınılmaz bir gerçektir. Bisiklet yürüyüş ile gerçekleştirilemeyecek orta mesafe ve kısa mesafelerde sürdürülebilir bir hareketlilik aracıdır (Pucher ve Buehler, 2017, s. 689). Ekonomik açıdan 
bireysel motorlu araç ile karşılaştırıldığında bisiklet en verimli araçlardan biridir. Gössling ve Choi (2015), Kopenhag örneğinde bireysel motorlu araç ile bisiklet kullanımını ekonomik olarak karşılaştırdıkları çalışmalarında motorlu araçların bisikletten yaklaşık altı kat daha maliyetli olduğu sonucuna ulaşmışlardır. Çalışmada bireysel motorlu araçta kilometre başına maliyetin 0,50 Euro, bisiklette ise kilometre başina 0,08 Euro olduğu sonucuna ulaşılmiştır.

Bisikletin kentte yaşayan her birey için erişilebilir ve tercih edilebilir olabilmesi için yaygın bisiklet ulaşım altyapısına ihtiyaç vardır. Kentsel bisiklet altyapısı bisiklet yolları, şeritler ve araç yollarından oluşmaktadır. Altyapıya ilişkin en uygun çözüm bisiklet yolları aracılığı ile kullanıcıları trafikten ayırmaktır. Bisiklet yollarının inşasının mümkün olmadığı yerlerde şeritlerden yararlanılmalıdır. Bisiklet yolu ve şeritlerin bulunmadığı yerlerde ise kullanıcllar yol ve kaldırımları tercih etmek durumda kalmaktadır (Heinen vd., 2010, s. 63). Güvenliğine ilişkin politikalar da bisikletin tercih edilmesi için dikkate alınması gereken önemli bir husustur. Sistemin güvenli olması için bisiklet yollarının ayrı olması, yayalar ile ortak kullanılabilecek özel alanların varlığı, kavşaklarda bisiklet güvenliğini sağlama araçları, güvenli park noktaları ve yol üzeri korunaklı bisiklet noktalarının oluşturulması gerekmektedir. Güvenli bir altyapı geniş ölçekli yatırımı ve mevcut altyapının geliştirilmesini zorunlu kılmaktadır. Bisiklet altyapısının güvenli ve erişilebilir olması için uygulanabilecek politikalardan biri bisiklet otoyollarıdır (cycle superhighways). Bu otoyollar mevcut yolların paralelinde sadece bisiklet kullantcılarına açık doğrudan rotalardır. Bisiklet otobanlarının olmadığı, kullanıc1ların kent trafiğine katılmak durumunda kaldığı noktalarda yeşil dalga uygulamaları ile bisikletlere öncelik verilmesi erişim kapsamında dikkate alınacak bir diğer husustur. Bisiklet altyapısının güvenli ve tercih edilebilir olmasını sağlamanın yollarından biri de kapsamlı trafik yavaşlatma politikalarıdır. Kentlerin belirli bölgelerinde yasal hız sınırının saatte 30 kilometre ve altına indirilmesi bisiklet kullanımını ve yürüyüşü kolaylaştırmaktadır (Pucher ve Buehler, 2017, s. 690-692).

Bisiklet paylaşım ve tamir istasyonları yaygın bir bisiklet altyapısının temel unsurlarındandır. Bisiklet sahibi olmayanların hareketlilik ihtiyacını karşılaması ve uzak mesafede bisiklet kullanımını sağlaması paylaşım istasyonlarının avantajlarıdır (DeMaio, 2009, s. 43). Elektronik kartlar ile kiralamanın yapılabilmesi gibi teknoloji ile entegre uygulamalar istasyonların kullanımını kolaylaştırmaktadır. Bu çerçevede uygulanabilecek bir diğer politika elekt- 
rikli bisiklet paylaşım noktalarının oluşturulmasıdır. İlk uygulamanın başladığı Çin'de ve Kuzey Avrupa ülkelerinde yaygın bir şekilde kullanılan ortak elektrikli bisikletler uzun mesafede, engebeli alanlarda ulaşıma imkân sağlamaktadır (Pucher ve Buehler, 2017, s. 692). Pandemi sürecinde aynı yüzeyin farklı bireyler tarafından kullanılması paylaşım istasyonlarında bulaş riskini ortaya çıkarmaktadır. Bu çerçevede ilgili hijyen önlemlerinin alınması ile bisiklet paylaşımının teşvik edilmesi mümkündür (Lozzi vd., 2020, s. 16). Bisiklet kullanımına ilişkin son husus bisikletin diğer türler ile entegrasyonunun sağlanmasıdır. Toplu taşıma araçlarında bisiklet taşıma alanlarının bulundurulması, duraklarda korunaklı park alanlarının kurulması, çok işlevli bisiklet istasyonlarının (bakım, onarım, kiralama, bilgilendirme gibi hizmetleri sunan merkezler) kurulması, bisiklet altyapısının diğer ulaşım türleri dikkate alınarak oluşturulması bu doğrultuda uygulanabilecek politikalardır (Pucher ve Buehler, 2009, s. 81).

Değişimin ikinci yolu toplu taşıma sisteminin yaygınlaştırılması, etkinliğinin sağlanması ve erişilebilirliğin arttırılmasına yönelik politikalardır. Toplu taşımanın çevresel ve ekonomik maliyeti bireysel araç ile karşılaştırıldığında daha düşük düzeydedir. Ancak bireysel araçlarda güvenlik, hız, konfor gibi alanlarda yaşanan gelişmeler bireysel araçları toplu taşıma karşısında daha cazip k1lmaktadır (Yavuz, 2015, s. 551). Mevcut toplu taşıma sisteminin tehlikeli, belirsiz ve sistemsiz olması bireyleri özel araç kullanmaya itmektedir (Zamora, 2014, s. 148). Alternatifleri arttırması, trafik sıkışıklığını azaltması, yakıt tasarrufu sağlaması, sosyal kaynaşmayı sağlaması, maliyetleri düşürmesi toplu taşımayı bireysel araçlara kıyasla daha sürdürülebilir kılmaktadır. Pandemi sürecinde toplu taşıma kullanımı bulaş riski nedeniyle düşmüştür. Bununla birlikte Avusturya, Fransa ve Japonya'da virüs yayılımına ilişkin yapılan araştırmalar uygun önlemler alındığı takdirde toplu taşımada virüs bulaşma riskinin düşük olduğunu göstermektedir (Lozzi vd., 2020, s. 14; OECD, 2020, s. 14-15).

Değişim çerçevesinde toplu taşımaya ilişkin atılması gereken ilk adım kentlerin temel hareketlilik gereksinimlerini karşılayacak toplu taşıma türlerinin (otobüs, minibüs, hafif raylı sistemler, metro, metrobüs ve paratransit taşıtlar) belirlenmesidir. Verimlilik, hijyen, çevresel maliyet ve performans dikkate alınarak uygulanacak toplu taşıma sistemi kentte yaşayan her birey açısından erişilebilir ve tercih edilebilir olmalıdır (Gwilliam, 2002, s. 112). Toplu taşımaya erişimde sorun yaşayan ve ekonomik durumu uygun olan bireyler bu çerçevede bireysel araçlara yönelmektedir. Toplu taşıma sisteminin erişilebilir olması kentsel alanının tamamını kapsayacak şekilde rotaların 
ve koridorların kurulması ile mümkündür (Dodson, Mees, Stone ve Burk, 2011). Toplu taşımaya erişilebilirlik açısından özellikle büyük kentlerde bireylerin birden fazla aracı kullanması zorunlu olmaktadır. Bu durum toplu taşıma araçları arasında entegrasyonu gerekli kılmaktadır. Entegrasyonun ilk aşaması farklı ulaşım türlerine erişilebilen aktarma merkezlerinin oluşturulmasıdır. Bu merkezler temelinde seyahat edecek vatandaşlar için zaman, ücret ve yönetim entegrasyonu sağlanmalıdır. Herhangi bir toplu taşıma aracını kullanacak birey belirli süre içerisinde diğer toplu taşıma araçlarına erişebilir olmalıdır (Yavuz, 2015, s. 558). Toplu taşıma araçlarına geçiş üstünlüğü sağlanması, belirli saatlerde sadece toplu taşımaya ayrılmış yolların kullanılması erişilebilirliği arttırmanın araçlarıdır (Yavuz, 2015, s. 561). Toplu taşımanın tercih edilebilir olması için toplu taşıma araçları ile birlikte toplu taşıma istasyonlarının da uygun olması gerekmektedir. İstasyonların güvenli, konforlu ve hava koşullarına karşı korunaklı olması toplu taşımayı tercih edilebilir kılmaktadır. Tercih edilebilirlik açısından bir diğer önemli nokta toplu taşımanın makul fiyatlandırılmasıdır. Toplumun farklı kesimlerine yönelik (öğrenci, yaşlı vb.) fiyatlandırma ölçütleri belirlenmelidir. Makul fiyatlandırmanın bir diğer uygulama şekli toplu taşımayı bireylerin kullandıkları mesafe kadar fiyatlandırmaktır (Dodson vd., 2011, s. 20-21). Ödeme, iniş-biniş sistemlerinin geliştirilmesi, esnek zamanlı uygulamalar erişilebilirlik ve tercih edilebilirlik için yapılabilecek uygulamalardır. Ödeme açısından bütün toplu taşıma araçlarında kullanılabilecek akıllı kart sisteminin varlığı kolaylaştırıcı bir unsurdur. Kart sisteminde önceden yüklemelerle kolaylık ve zaman kayıplarının önlemesi sağlanabilir. Esnek zamanlı uygulamalara zirve saatler dışında indirimli bilet uygulaması örnek olarak verilebilir (Yavuz, 2015, s. 560; Zamora, 2014, s. 148). Seyahat süresi ve istasyonlara ilişkin eş zamanlı bilgilendirme sağlayacak akıllı uygulamalar toplu taşımaya erişimin arttırılmasının bir diğer aracıdır (Civitas, 2014, s. 6). Park et ve devam et (Park and Ride) sistemi toplu taşımaya teşvik amaçlı yapılabilecek uygulamalardan biridir. Sistemde bireyler özel araçlarını park ederek toplu taşımaya geçiş yapmaktadır. Burada asıl amaç toplu taşıma ile hareketliliğin sağlanmasıdır (Yavuz, 2015, s. 561). Toplu taşımada otobüs, metro, tramvay gibi seçeneklerin yanında hayata geçirilebilecek bir diğer sistem metrobüs (BRT) uygulamasidır. Metrobüs sisteminin avantajları trafikten bağımsız bir koridora sahip olması, uygun fiyatlarla kent yoksulları dâhil olmak üzere her bireyi taşıyabilmesi, yolcu kapasitesinin yüksek olması, iniş-biniş sürelerinin kısa olması, eş zamanlı bilgilendirmeye daha uygun olmasl, seferler arasında ücretsiz trans- 
ferlere imkân sağlamasıdır. Bu sistemin olumsuz yanları ise ulaşım koridorunun oluşturulabilmesi için uygun alan ihtiyacı ve yapım maliyetinin yüksek olmasıdır (Asian Development Bank, 2009, s. 41; Dalkmann ve Brannigan, 2007, s. 11).

K-D-G anlatısının "gelişim boyutu" ise ulaşım araçlarının çevresel tahribatı azaltacak şekilde verimliliklerinin sağlanmasını ifade etmektedir. Kent yönetimlerinin ulaşım araçlarında düşük karbonlu yakıt türlerinin tercih etmesi gelişime dönük temel noktadır. Hidrojen, elektrik, biodizel, biometan bu doğrultuda dikkate alınması gereken yakıt türleridir. (Lewis, 2015, s. 23). Kent yönetiminin düşük karbonlu yakıt türlerinin yaygınlaşmasına ilişkin yapabileceği uygulamalar temiz yakıt altyapısının oluşturulması (elektrikli araç şarj noktaları vb.), sadece belirli araçların girebildiği düşük salınım bölgelerinin oluşturulması, mevcut kamusal araç filosunun bakımı, tamiri ve parklanma gibi süreçlerde verimli araçlara fiyat indirimi yapılmasıdır (Zamora, 2014, s. 148).

\section{Sonuç}

Barbarossa (2020, s. 2) ve Nikitas (2021, s. 4)'ın da dile getirdiği üzere Covid krizi, fosil yakıtlara bağımlılık, artan karbon emisyonları, biyo-çeşitlilik kaybı, konut piyasalarındaki eşitsizlikler, zenginler ile fakirler arasındaki bölünmeler ve marjinallik gibi uzun vadeli kentsel sorunlara ve bugüne kadar dünyamızı yönetme şeklimizin sınırlarına yeni bir bakış açısı sundu. Karantinaların başlangıcından itibaren, medya, politikacılar, planlamacılar ve araştırmacılar tarafından, geleceğimizi yeniden tasarlamak, kentsel alanları yeniden düşünmek ve sakinlerinin ihtiyaçlarına cevap vermek için dünyanın dört bir yanındaki önlemlerle ilgili olarak gerçekleştirilen ateşli tartışmalara tanık olduk. Bu tartışmalar pandeminin ulaşım üzerindeki etkisine odaklanan henüz sınırlı, ancak büyük ölçüde artan sayıda çalışmayı da beraberinde getirdi. Bu çalışmaların gösterdiği üzere, hareketlilik tarzları normal koşullarda değişime karşı dirençli olmakla birlikte, Covid-19 tedbirleri kentsel hareketlilik kalıplarını büyük ölçüde değiştirmiştir. Bir taraftan Covid krizinin gerektirdiği sosyal mesafe ihtiyacı, toplu taşıma sistemlerinin tam kapasite çalışamamasına ve özel araçlara kıyasla rekabet gücünü kaybetmesine neden olmuştur. Diğer taraftan da Covid-19 sonrasında önemli bir gelişme alternatif ulaşım modlarının ve özellikle aktif hareketliliğin rolü ve kullanımı bağlamında ortaya çıkmış, sosyal mesafenin birdenbire zorunlu hale geldiği bir bağlamda, bisiklet ve scooter kullanımında bir artışın yanı sıra e-bisiklet ve e-scooterların popülaritesinde de bir artış yaşanmıştır. Yine bu süreçte kent yönetimleri 
kapanmayı fırsat bilerek birtakım yolları araç trafiğine kapatırken daha önce araçların işgal ettiği alanları bisiklet ve yayalara açmış; sosyal mesafeyi korumak adına yayalaştırılan alanlarla birlikte sokak mekânı yeniden kazanılmıştır. Kamusal mekânların daha esnek kullanımına ve bireysel araç kullanımı dışında hareketlilik alternatiflerine dönük bir eğilim kentlerimizin nasıl olduğu ve nasıl olması gerektiğinin sorgulanmasını da beraberinde getirmiştir. Tüm bu olumlu gelişmelere rağmen pandemi sonrası ulaşıma ilişkin dile getirilen farklı senaryolar göstermektedir ki virüsün etkilerinin azalması ve ortadan kalkmasıyla birlikte, insanların eski alışkanlıklarına ve kentsel hareketliliğin de virüs öncesi döneme dönmesi olasıdır. Bir diğer senaryo ise belirsizliğin devam etmesi durumunda özel araca dönük talebin artması yönündedir. Her iki senaryonun gerçekleşmesi halinde krizden ders çıkaramadığımız anlamına gelir. Asıl olan pandemi krizini, sürdürülebilir hareketlilik projelerini keşfetmek veya teşvik etmek için bir fırsat olarak görmektir. Yani pandemi sonrasında bizler artık "ne" yapmamı gerektiğini büyük ölçüde biliyoruz, sadece "nasıl" sorusunun yanitına ve bu sorunun yanitını bizlere verecek anlatılara ihtiyacımız var. Kanaatimizce seyahat ihtiyacını azaltmak/seyahatten kaçınmak, çevreye duyarlı ulaşım türlerine geçiş ve kaynak verimliliğinin sağlanması için yapılması gerekenleri ifade eden Kaçınma-DeğişimGelişim anlatısı büyük ölçüde nasıl sorusunun yanıtını içinde saklamaktadır. 


\section{Extended Abstract}

\section{Avoid, Shift, Improve: A Narrative for Sustainable Mobility in the New Normal}

\author{
Hülya Eşki Uğuz 6 \\ ORCID: 0000-0003-1583-0501
}

\author{
Firat Harun Y1lmaz ${ }^{7}$ \\ ORCID: 0000-0003-2838-5400
}

Urban mobility shapes urban development and transformation since 19th century. With the population growth experienced in cities and the urban sprawl, car use has become an ordinary part of life. Urban mobility planning and policymaking are based upon car-oriented culture. Mobility is one of the main ways of urban economic development. But at the other side of the medallion, car-oriented mobility modes cause problems in the cities. Besides urban development, mobility causes externalities in the urban environment, society, and the urban economy. Environmental problems like air pollution, ecosystem destruction, social issues like the decline in quality of life, and economic issues like resource depletion, infrastructure costs are examples of effects caused by caroriented mobility. The measures taken during the pandemic have changed the patterns of urban mobility. The pandemic provides an opportunity to rethink urban mobility and the city within the alternatives of car-depended mobility. In the post-pandemic new normal, considering urban mobility within the caroriented culture will cause problems to continue in the long term. In the process of rethinking urban mobility, new policies are needed. Policies are important not only in terms of describing concepts but also in terms of determining basic principles and road maps. These policies need to consider mobility as a sustainability and livability issue, not only the technical issue. Policies that meet the need for urban mobility by preventing problems are one of the main goals of every city administration. The policies we need in the name of sustainable mobility should include a consistent set of actions, main strategies, key actors, and roles to achieve sustainable mobility. The policies of sustainable mobility need

\footnotetext{
${ }^{6}$ Prof. Dr., Selcuk University, E-mail: hulyaeski@selcuk.edu.tr

${ }^{7}$ R. A., Selcuk University, E-mail: firatyilmaz@selcuk.edu.tr
} 
to be compatible with three conditions of sustainable development, namely meeting human needs, ensuring social justice, and respecting planetary boundaries. In this context, accessibility, equality, and environmental sustainability emerge as the main principles of sustainable mobility. In this process, a longterm approach is needed in which the spread of mobility infrastructure is not considered the only solution. In other words, sustainable urban mobility policies are needed for the cities of the future. Another consideration for sustainable mobility is to recognize that urban mobility will cause problems without good planning and management.

Making urban mobility sustainable is one of the ways to create a livable city by eliminating the negative effects of traditional urban mobility policies. Sustainable mobility represents an ideal that is separate from the traditional transportation approach applied in most cities today. Unlike the traditional car-oriented approach, the sustainable mobility approach is accessibility-oriented. The approach focusing on the integration of different transport modes takes the social and environmental impacts of mobility besides the economic impacts. Sustainable mobility is based on walking, cycling, and public transport. It is an economically efficient, socially sensitive, and environment-friendly understanding of mobility. Sustainable mobility places people at the center rather than cars. The study aims to address the sustainable mobility narrative Avoid-Shift-Improve which emphasizes processes such as promoting active mobility, focusing on public transportation, leaving car-dependent culture. Avoid-Shift-Improve is one of the approaches used in framing sustainable urban mobility policies. Avoid addresses what needs to be done to reduce the need for travel or avoid travel. Shift emphasizes alternative environment-friendly transport modes. Improve addresses the ways of resource efficiency. The first way to achieve avoid is urban planning. The second way is to develop solutions through technologies. In the pandemic process, mobility avoidance become a necessity. Distance education, distance learning, flexible working patterns, the spread of virtual conferences and meetings result in a decrease or avoidance of the need for mobility. Other avoid policies listed as pricing policies for cars, smart traffic tools, car-sharing, raising awareness. The first dimension of shift policies is active mobility. Within active mobility, the first issue is walking. Walking requirements for sustainable urban mobility are listed as compact planning, city lighting in terms of safety and comfort, walkable streets, the presence of tools that assist pedestrians (guidance signs, information signs, public toilets, urban furniture). The second issue is the bicycle. Bicycle infrastructure expansion and promotion 
policies, safety-related policies, bicycle highways, traffic slowing policies, bicycle sharing and repair stations, accessible and widespread infrastructure are the policy fields in this issue. The second dimension of the shift policies is public transport. At this point, policies aimed at expanding the public transport system, ensuring its effectiveness, and increasing accessibility become important. Other issues are the integration of public transport, development of smart systems, flexible time applications. The improve dimension of the A-S-I refers to ensuring the efficiency of transport modes in a way that reduces environmental destruction. Hydrogen, electricity, biodiesel, biomethane are the types of fuels that should be considered in this direction. At this point the expansion of the transport infrastructure for new types of fuel is important.

In the new normal, one of the scenarios related to mobility is the situation when urban mobility returns to its pre-pandemic state. In this case, urban mobility will remain a fundamental problem area. Another scenario is the transition to sustainable mobility. In this scenario sustainable urban mobility policy is one of the cornerstones for creating livable cities of the future. Urban mobility in the new normal requires transition to sustainable mobility policies. Within this framework, it needs to ask that how this transition is addressed. As a result of the study, it is stated that Avoid-Shift-Improve is one of the potential frameworks for the transition to sustainable urban mobility policies in the new normal.

\section{Kaynakça/References}

Aftabuzzaman, Md. ve Mazloumi, E. (2011). Achieving sustainable urban transport mobility in post peak oil era. Transport Policy, 18(5), 695-702.

Akyol, İ. (2013). Kentiçi ulaşım. TMMOB 2. İzmir Kent Sempozyumu Bildiriler Kitabr içinde (ss. 297-303). İzmir: TMMOB İzmir İl Koordinasyon Kurulu.

Asian Development Bank (2009). Changing course a new paradigm for sustainable urban transport. Philippines: Asian Development Bank Publications.

Bakker, S., Zuidgeest, M., De Coninck, H. ve Huizenga, C. (2014). Transport, development and climate change mitigation towards an integrated approach. Transport Reviews, 34(3), 335-355.

Banister, D. (2008). The sustainable mobility paradigm. Transport Policy, 15(2), 73-80.

Barbarossa, L. (2020). The post pandemic city: challenges and opportunities for a nonmotorized urban environment. an overview of Italian cases. Sustainability, 12(17), $1-20$. 
Bert, J., Schellong, D., Hagenmaier, M., Hornstein, D., Wegscheider, A. K. ve Palme, T. (2020). How Covid-19 will shape urban mobility. 21 Ağustos 2021 tarihinde https://www.bcg.com/publications/2020/how-covid-19-will-shape-urbanmobility adresinden erişildi.

Beyazıt, E. (2021), Sürdürülebilir ulaşım ve hareketlilik. 27 Ağustos 2021 tarihinde https://mekandaadalet.org/wp-

content/uploads/2021/04/mad_10_SurdurulebilirUlasim_single_ed3.pdf adresinden erişildi.

Bos, R. ve Temme, R. (2014). A roadmap towards sustainable mobility in Breda. Transportation Research Procedia, 4, 103-115.

Bräuninger, M., Schulze, S., Leschus, L., Perschon, J., Hertel, C., Field, S. ve Foletta, N. (2012). Achiving sustainability in urban transport in developing and transition $\begin{array}{lllll}\text { countries. } & 25 & \text { Ağustos } & 2021 & \text { tarihinde }\end{array}$ https://www.umweltbundesamt.de/sites/default/files/medien/461/publikatione n/4239.pdf adresinden erişildi.

Budd, L. ve Ison, S. (2020). Responsible transport: a post-covid agenda for transport policy and practice. Transportation Research Interdisciplinary Perspectives, 6, 100151.

Cheba, K. ve Saniuk, S. (2016). Sustainable urban transport-the concept of measurement in the field of city logistics. Transportation Research Procedia, 16, 35-45.

Cirit, F. (2014). Sürdürülebilir kentiçi ulaşım politikaları ve toplu taşıma sistemlerinin karşılaştırılması. Yayımlanmamış uzmanlık tezi. Kalkınma Bakanlığı, Ankara.

Civitas (2014). Enhancing the quality of public transport services making public transport more attractive for citizens. 22 Ağustos 2021 tarihinde http://civitas.eu/sites/default/files/civitas_ii_policy_advice_notes_11_public_tra nsport_quality.pdf adresinden erişildi.

Comune di Milano (2020). Milan 2020 adaptation strategy. 22 Ağustos 2021 tarihinde https://www.comune.milano.it/documents/20126/7117896/Open+streets.pdf/d9 be0547-1eb0-5abf-410b-a8ca97945136?t=1589195741171. adresinden erişildi.

Çelik, M. (2009). Sürdürülebilir ulaşım ve Türkiye kentleri ulaşım sorunları. TMMOB 1. İzmir Kent Sempozyumu Bildiriler Kitabı içinde (ss. 703-711). İzmir: TMMOB İzmir İl Koordinasyon Kurulu.

Dalkmann, H. ve Brannigan, C. (2007). Transport and climate change. sustainable transport a sourcebook for policy-makers in developing cities. 20 Ağustos 2021 tarihinde https://www.gtkp.com/assets/uploads/20091123-095443-16925e_TCC.pdf. adresinden erişildi.

DeMaio, P. (2009). Bike-sharing: history, impacts, models of provision, and future. Journal of Public Transportation, 12(4), 41-56.

Deponte, D., Fossa, G. ve Gorrini, A. (2020). Shaping space for ever-changing mobility. Covid-19 lesson learned from Milan and its region. TeMA-Journal of Land Use, Mobility and Environment, Special Issue, 133-149. 
Dodson, J., Mees, P., Stone, J. ve Burk, M. (2011). The principles of public transport network planning: a review of the emerging literature with select examples. 21 Ağustos 2021 tarihinde https://apo.org.au/node/53363. adresinden erişildi.

Dovey, K. ve Pafka, E. (2020). What is walkability? the urban DMA. Urban studies, 57(1), 93-108.

Erdoğan, Ö. (2014). Günümüzde belediyelerin sürdürülebilir kent-içi ulaşım (toplu taşımacılık) ile ilgili görev ve sorumlulukları. 16 Ağustos 2021 tarihinde http://abmyod.aydin.edu.tr/makaleler/sayi_44/gunumuzde-belediyelerinsurdurulebilir.pdf. adresinden erişildi.

Forbes (2021). Urban transformation post-pandemic: not business as usual. 28 Ağustos 2021 tarihinde https://www.forbes.com/sites/deloitte/2021/08/30/urbantransformation-post-pandemic-not-business-as-usual/?sh=738c7e2534f1. adresinden erişildi.

Global Transport Knowledge Partnership. (2020). Avoid-shift-improve. 18 Ağustos 2021 tarihinde https://www.gtkp.com/themepage.php\&themepgid=477. adresinden erişildi.

Goldman, T. ve Gorham, R. (2006). Sustainable urban transport: four innovative directions. Technology in Society, 28(1-2), 261-273.

Gorrini, A. ve Bertini, V. (2018). Walkability assessment and tourism cities: the case of Venice. International Journal of Tourism Cities, 4(3), 355-368.

Gössling, S. ve Choi, A. S. (2015). Transport transitions in Copenhagen comparing the cost of cars and bicycles, Ecological Economics, 113, 106-113.

Griffiths, S., Del Rio, D. F. ve Sovacool, B. (2021). Policy mixes to achieve sustainable mobility after the Covid-19 crisis. Renewable and Sustainable Energy Reviews, 110919.

Gudmundsson, H. (2004). Sustainable transport and performance indicators. Issues in environmental science and technology, 20, 35-64.

Gudmundsson, H., Marsden, G., Hall, R. P. ve Josias, Z. (2016). Sustainable transportation: indicators, frameworks, and performance management. Heidelberg: Springer.

Haghshenas, H. ve Vaziri, M. (2012). Urban sustainable transportation indicators for global comparison. Ecological Indicators, 15(1), 115-121.

Heinen, E., Van Wee, B. ve Maat, K. (2010). Commuting by bicycle: an overview of the literature. Transport Reviews, 30(1), 59-96.

Heinonen, J., Czepkiewicz, M., Árnadóttir, Á. ve Ottelin, J. (2021). Drivers of car ownership in a car-oriented city: a mixed-method study. Sustainability, 13(2), 619.

Holden, E., Banister, D., Gössling, S., Gilpin, G. ve Linnerud, K. (2020). Grand narratives for sustainable mobility: a conceptual review. Energy Research E Social Science, 65, 101454

Holden, E., Linnerud, K. ve Rygg, B. J. (2021). A review of dominant sustainable energy narratives. Renewable and Sustainable Energy Reviews, 144, 1-11 
Jafri, J. (2014). Sustainable practices in urban transport: avoiding, shifting, improving in Karachi. 20 Ağustos 2021 tarihinde http://southasiajournal.net/sustainablepractices-urban-transport-avoiding-shifting-improving-karachi/ adresinden erişildi.

Jaiswal, A., Rathore, K. R. ve Jain, D. (2012). Sustainable transit oriented development: solving congestion problem at Delhi. International Journal of Sustainable Development, 3(8), 59-68.

Katzev, R. (2003). Car sharing a new approach to urban transportation problems. Analyses of Social Issues and Public Policy, 3(1), 65-86.

Kennedy, C., Miller, E., Shalaby, A., Maclean, H. ve Coleman, J. (2005). The four pillars of sustainable urban transportation. Transport Reviews, 25(4), 393-414.

Knoflacher, H. ve Öcalır, E. V. (2011). Sürdürülebilir ulaşım kavramı üzerine tartışmalar. Türkiye Mühendislik Haberleri, 468, 51-58.

Lewis, E. (2015). Green city development tool kit. Philippines: Asian Development Bank.

Lidskog, R., Elander, I. ve Brundin, P. (2003). Towards sustainable urban transportation in the European Union?. N. Low ve B. Gleeson (Der.), Making Urban Transport Sustainable içinde (ss. 223-239). Hampshire: Palgrave Macmillan.

Litman, T. (2016). Developing indicators for sustainable and liveable transport planning. Canada: Victoria Transport Policy Institute

Low, N. (2003). Is urban transport sustainable?. N. Low ve B. Gleeson (Der.), Making Urban Transport Sustainable içinde (ss. 1-22). Hampshire: Palgrave Macmillan.

Lozzi, G., Rodrigues, M., Marcucci, E., Teoh, T., Gatta, V. ve Pacelli, V (2020). Research for TRAN committee Covid-19 and urban mobility: impacts and perspectives. 25 Ağustos $2021 \quad$ tarihinde https://www.europarl.europa.eu/RegData/etudes/IDAN/2020/652213/IPOL_ID A(2020)652213_EN.pdf. adresinden erişildi.

Macário, R. ve Marques, C. F. (2008). Transferability of sustainable urban mobility measures. Research in Transportation Economics, 22(1), 146-156.

Meakin, R. (2004). Sustainable transport: a sourcebook for policy-makers in developing cities urban transport institutions. Germany: GTZ (Deutsche Gesellschaft für Internationale Zusammenarbeit) Publication.

Mert, K. ve Öcalır, E. V. (2010). Konya'da bisiklet ulaşımı: planlama ve uygulama süreçlerinin karşılaştırılması. METU Journal of the Faculty of Architecture, 27(1), 223-240.

Nikitas, A. (2021). Cycling in the era of Covid-19: lessons learnt and best practice policy recommendations for a more bike-centric future. Sustainability, 13(9), 1-25

Organisation for Economic Co-operation and Development [OECD]. (1996). Towards sustainable transportation the Vancouver conference. 21 Ağustos 2021 tarihinde https://www.oecd.org/greengrowth/greening-transport/2396815.pdf. adresinden erişildi.

Organisation for Economic Co-operation and Development [OECD]. (2020). Policy responses to coronavirus (Covid-19). cities policy responses. 27 Ağustos 2021 
tarihinde

https://read.oecd-ilibrary.org/view/?ref=126_126769yen45847kf\&title=Coronavirus-COVID-19-Cities-Policy-Responses. adresinden erişildi.

Pucher, J. ve Buehler, R. (2009). Integrating bicycling and public transport in North America. Journal of Public Transportation, 12(3), 79-104.

Pucher, J. ve Buehler, R. (2017). Cycling towards a more sustainable transport future. Transport Reviews, 37(6), 689-694.

Rietveld, P. ve Daniel, V. (2004). Determinants of bicycle use: do municipal policies matter? Transportation Research Part A: Policy and Practice, 38(7), 531-550.

Rodrigue, J., Comtois, C. ve Slack, B. (2016). The geography of transport systems. Taylor Francis.

Schiller, P. L. ve Kenworthy, J. R. (2017). An introduction to sustainable transportation: policy, planning and implementation. Routledge.

Schiller, P. L., Bruun, E., Kenworthy J. R. (2010). An introduction to sustainable transportation policy, planning and implementation. Earthscan Publications

Schiller, P. ve Kenworthy, J. (1999). Prospects for sustainable transportation in the Pacific Northwest: a comparison of Vancouver, Seattle and Portland. World Transport Policy and Practice, 5, 30-38.

Speck, J. (2013). Walkable city: how downtown can save America, one step at a time. North Point Press.

Tran, T. M. (2020). Pandemi sokaklarımızı, mahallemizi ve hayat tarzımızı sorgulamak için benzersiz bir fursat. 28 Ağustos 2021 tarihinde https://www.iklimhaber.org/pandemi-sokaklarimizi-mahallemizi-ve-hayattarzimizi-sorgulamak-icin-benzersiz-bir-firsat/. adresinden erişildi.

Wheeler, S. M. (2004). Planning for sustainability: creating livable, equitable and ecological communities. Routledge.

Yargıç, İ. (2021). Hareketlilik ve iklim. Spektrum-Mobilite: Mekansal Hareketlilik, Devingenlik, Akışkanlık. 4, 9-12.

Yavuz, N. (2015). Toplu ulaşım kullanımını teşvik politikaları. M. Yıldız ve M. Z. Sobacı (Der.) Kamu Politikası Kuram ve Uygulama içinde (ss. 550-565). Ankara: Adres Yayınları.

Zamora, J. C. P. (2014). The "avoid-shift-improve" model a powerful planning tool for transportation schemes with low GHG emissions. MIPALCON Conference Prooceedings Climate Change-A Global Challenge. Contribution of Infrastructure Planning içinde (ss. 141-150). Germany: University of Stuttgart. 